九州大学学術情報リポジトリ

Kyushu University Institutional Repository

\title{
Studies on Biologically Active
} Guanidinopyrimidines Part II. : Effect of Guanidinopyrimidines on Phytopathogens

Shuto, Yoshihiro

Laboratory of Pesticide Chemistry, Faculty of Agriculture, Kyushu University

Taniguchi, Eiji

Laboratory of Pesticide Chemistry, Faculty of Agriculture, Kyushu University

Maekawa, Kazuyuki

Laboratory of Pesticide Chemistry, Faculty of Agriculture, Kyushu University

https://doi.org/10.5109/23684

出版情報：九州大学大学院農学研究院紀要. 23 (3/4)，pp. 125-132，1979-03. Kyushu University バージョン：

権利関係 : 


\title{
Studies on Biologically Active Guanidinopyrimidines Part II*. Effect of Guanidinopyrimidines on Phytopathogens
}

\author{
Yoshihiro Shuto, Eiji Taniguchi and Kazuyuki Maekawa \\ Laboratory of Pesticide Chemistry, Faculty of Agriculture, \\ Kyushu University 46-02, Fukuoka 812 \\ (Received October 12, 1978)
}

\begin{abstract}
Fifteen new guanidinopyrimidine derivatives were prepared and their fungicidal and antiviral activities were examined. The quantitative structure-activity relationship was also examined. At a relatively high concentration 2-benzylguanidino4-phenyl-6-methylpyrimidine was as effective as validamycin against Pellicularia sasakii and as edifenphos against Pyricularia oryzae. 2-Phenylpropylguanidino-4-phenyl-6-methylpyrimidine effectively blocked the invasion by Pseudoperonosporacubensis. In the antiviral test against TMV, some compounds were fairly effective at $100 \mathrm{ppm}$ level.
\end{abstract}

\section{INTRODUCTION}

Pyrimidine derivatives have attracted particular interest as fungicides (Woodcock, 1972), since Elias et al. (1968) reported a systemic fungicide dime. thirimol (5-butyl-2-dimethylamino-4-hydroxy-6-methylpyrimidine), and its analogue ethirimol (5-butyl-2-ethylamino-4-hydroxy-6-methylpyrimidine) (Bebbington et al., 1969). While, guanidinopyrimidine derivatives are known to be potent antimalarial drugs (Curd and Rose, 1946; Urbanski and Serafin, 1967; Elslager et al., 1974).

In a previous paper, we reported the syntheses of guanidinopyrimidine derivatives and their biological activities against plants, insect and cultured cells (Shuto et al., 1974). 2-Phenethylguanidino-4,6-dimethylpyrimidine almost inhibited the growth of radish roots at $50 \mathrm{ppm}$, while at lower concentrations it stimulated their growth remarkably. In the case of the moulting process in a housefly strain, 4,6-dimethylpyrimidine derivatives delayed its pupation. On the other hand, 4-hydroxy-6-methyl derivatives seemed to accelerate it.

This paper describes the preparation of 15 new guanidinopyrimidines and their biological activities against fungi and tobacco mosaic virus.

\section{MATERIALS AND METHODS}

\section{Chemicals}

The new compounds prepared were enumerated in Tables 1 and 2 . Melting points were uncorrected. NMR spectra were recorded on a JEOL nuclear

\footnotetext{
* For Part I, see Reference Shuto et al., 1974.
} 
Table 1. Analytical data of guanidinopyrimidines.<smiles>[R5]c1nc(NC(=N)N([R2])[R2])nc([R5])c1[R]</smiles>

\begin{tabular}{|c|c|c|c|c|c|c|c|c|c|c|}
\hline \multirow{2}{*}{$\begin{array}{l}\text { Compd. } \\
\text { No. } \\
1\end{array}$} & \multirow{2}{*}{$\begin{array}{r}R_{1} \\
\text { i-Pr }\end{array}$} & \multirow{2}{*}{$\begin{array}{l}\mathrm{R}_{2} \\
\mathrm{H}\end{array}$} & \multirow{2}{*}{$\begin{array}{l}\mathrm{R}_{3} \\
\mathrm{OH}\end{array}$} & \multirow{2}{*}{$\begin{array}{r}\mathrm{R}_{4} \\
\mathrm{H}\end{array}$} & \multirow{2}{*}{$\begin{array}{l}\mathrm{R}_{5} \\
\mathrm{CH}_{3}\end{array}$} & \multirow{2}{*}{$\begin{array}{l}\text { Yield } \\
(\% 6) \\
30\end{array}$} & \multirow{2}{*}{$\begin{array}{l}\text { M. p. } \\
\left({ }^{\circ} \mathrm{C}\right) \\
290\end{array}$} & \multicolumn{3}{|c|}{$\begin{array}{l}\text { Elemental Analysis } \\
\mathrm{C}{ }_{\text {(Found/Calcd.) }}{ }_{1 \mathrm{~N}}\end{array}$} \\
\hline & & & & & & & & $\begin{array}{l}51.22 \\
51.66\end{array}$ & $\begin{array}{l}7.19 \\
7.23\end{array}$ & $\begin{array}{l}32.90 \\
33.47\end{array}$ \\
\hline 2 & $\mathrm{PhCH}_{2}$ & $\mathrm{H}$ & $\mathrm{OH}$ & $\mathrm{H}$ & $\mathrm{CH}_{3}$ & 57 & 305 & $\begin{array}{l}60.70 \\
60.68\end{array}$ & $\begin{array}{l}5.84 \\
5.88\end{array}$ & $\begin{array}{l}27.34 \\
27.22\end{array}$ \\
\hline 3 & $\mathrm{Ph}\left(\mathrm{CH}_{2}\right)_{3}$ & $\mathrm{H}$ & $\mathrm{OH}$ & $\mathrm{H}$ & $\mathrm{CH}_{3}$ & 49 & 284 & $\begin{array}{l}63.23 \\
63.14\end{array}$ & $\begin{array}{l}6.77 \\
6.71\end{array}$ & $\begin{array}{l}24.68 \\
24.55\end{array}$ \\
\hline 4 & $\mathrm{Ph}\left(\mathrm{CH}_{2}\right)_{s}$ & $\mathrm{H}$ & $\mathrm{CH}_{3}$ & $\mathrm{H}$ & $\mathrm{CH}_{3}$ & 36 & $195-7$ & $\begin{array}{l}67.87 \\
67.81\end{array}$ & $\begin{array}{l}7.52 \\
7.47\end{array}$ & $\begin{array}{l}24.85 \\
24.72\end{array}$ \\
\hline 5 & $\mathrm{PhCH}_{2}$ & $\mathrm{H}$ & $\mathrm{OH}$ & $\mathrm{H}$ & $\mathrm{Ph}$ & 46 & $305-6$ & $\begin{array}{l}66.73 \\
67.69\end{array}$ & $\begin{array}{l}5.49 \\
5.37\end{array}$ & $\begin{array}{l}22.00 \\
21.93\end{array}$ \\
\hline 6 & $\mathrm{Ph}\left(\mathrm{CH}_{2}\right)_{3}$ & $\mathrm{H}$ & $\mathrm{OH}$ & $\mathrm{H}$ & $\mathrm{Ph}$ & 17 & $275-6$ & $\begin{array}{l}68.64 \\
69.14\end{array}$ & $\begin{array}{l}6.11 \\
6.09\end{array}$ & $\begin{array}{l}20.40 \\
20.16\end{array}$ \\
\hline 7 & $\mathrm{Ph}\left(\mathrm{CH}_{2}\right)_{2}$ & $\mathrm{H}$ & $\mathrm{Ph}$ & $\mathrm{H}$ & $\mathrm{CH}_{3}$ & 20 & $150-1$ & $\begin{array}{l}72.18 \\
72.48\end{array}$ & $\begin{array}{l}6.44 \\
6.39\end{array}$ & $\begin{array}{l}21.11 \\
21.13\end{array}$ \\
\hline 8 & $\mathrm{Ph}\left(\mathrm{CH}_{2}\right)_{3}$ & $\mathrm{H}$ & $\mathrm{Ph}$ & $\mathrm{H}$ & $\mathrm{CH}_{3}$ & 39 & 144 & $\begin{array}{l}73.08 \\
73.01\end{array}$ & $\begin{array}{l}6.55 \\
6.71\end{array}$ & $\begin{array}{l}20.15 \\
20.28\end{array}$ \\
\hline 9 & $\mathrm{CH}_{3}$ & $\mathrm{H}$ & $\mathrm{Ph}$ & $\mathrm{H}$ & $\mathrm{CH}_{3}$ & 21 & $197-8$ & $\begin{array}{l}64.68 \\
64.71\end{array}$ & $\begin{array}{l}6.36 \\
6.27\end{array}$ & $\begin{array}{l}28.96 \\
29.03\end{array}$ \\
\hline 10 & $\mathrm{CH}_{3}$ & $\mathrm{CH}_{3}$ & $\mathrm{Ph}$ & $\mathrm{H}$ & $\mathrm{CH}_{3}$ & 28 & 208 & $\begin{array}{l}65.90 \\
65.86\end{array}$ & $\begin{array}{l}6.77 \\
6.71\end{array}$ & $\begin{array}{l}27.54 \\
27.43\end{array}$ \\
\hline 11 & $\mathrm{PhCH}_{2}$ & $\mathrm{H}$ & $\mathrm{CH}_{3}$ & $\mathrm{CH}_{3}$ & $\mathrm{CH}_{3}$ & 30 & 211 & $\begin{array}{l}66.99 \\
66.89\end{array}$ & $\begin{array}{l}6.96 \\
7.11\end{array}$ & $\begin{array}{l}26.04 \\
26.00\end{array}$ \\
\hline 12 & $\mathrm{Ph}\left(\mathrm{CH}_{2}\right)_{2}$ & $\mathrm{H}$ & $\mathrm{CH}_{3}$ & $\mathrm{CH}_{3}$ & $\mathrm{CH}_{3}$ & 64 & 196 & $\begin{array}{l}67.12 \\
67.81\end{array}$ & $\begin{array}{l}7.27 \\
7.47\end{array}$ & $\begin{array}{l}24.44 \\
24.72\end{array}$ \\
\hline 13 & $\mathrm{Ph}\left(\mathrm{CH}_{2}\right)_{2}$ & $\mathrm{H}$ & $\mathrm{OH}$ & $\mathrm{CH}_{2} \mathrm{CH}_{3}$ & $\mathrm{CH}$ & 50 & 194 & $\begin{array}{l}64.19 \\
64.19\end{array}$ & $\begin{array}{l}7.14 \\
7.07\end{array}$ & $\begin{array}{l}23.36 \\
23.40\end{array}$ \\
\hline
\end{tabular}

Table 2. Analytical data of guanidinopyrimidine analogues.<smiles>[R2]N([R2])C(=N)NC(N)=NC=O</smiles>

\begin{tabular}{|c|c|c|c|c|c|c|c|}
\hline $\begin{array}{l}\text { Compd. } \\
\text { No. }\end{array}$ & $R_{1}$ & $\mathrm{R}_{2}$ & $\begin{array}{l}\text { Yield } \\
(\%)\end{array}$ & M. ${ }^{\circ} \mathrm{p}$. & $\underset{\mathrm{C}}{\text { Elemental }}$ & $\underset{H}{\text { Analysis }}$ & $\underset{\mathbf{N}}{(\text { F ound } / \text { Calcd.) }}$ \\
\hline 14 & $\mathrm{PhCH}_{2}$ & $\mathrm{H}$ & 31 & $\overline{190}$ & $\begin{array}{l}58.63 \\
58.76\end{array}$ & $\begin{array}{l}6.15 \\
6.16\end{array}$ & $\begin{array}{l}28.39 \\
28.56\end{array}$ \\
\hline 15 & $\mathrm{Ph}\left(\mathrm{CH}_{2}\right)_{2}$ & $\mathrm{H}$ & 33 & 225 & $\begin{array}{l}60.39 \\
60.21\end{array}$ & $\begin{array}{l}6.67 \\
6.61\end{array}$ & $\begin{array}{l}26.97 \\
27.01\end{array}$ \\
\hline
\end{tabular}


magnetic resonance spectrometer $\mathrm{MH}-100$.

\section{2-Phenylpropylguanidino-4-hydroxy-6-methylpyrimidine (3)}

Phenylpropylbiguanide hydrochloride $(0.02$ mole $)$ was added in the ethanolic solution of sodium ethoxide $(0.02$ mole) and stirred for a while, then the precipitate was filtered off. After the solvent was evaporated, ethyl acetoacetate $\left(0.04\right.$ mole) was added and heated at $120-130^{\circ} \mathrm{C}$ for an hour. The precipitate was collected and thoroughly washed with methanol. The crude product was recrystallized from dimethylformamide to furnish white crystals. Yield $2.8 \mathrm{~g}(49 \%)$. M.p. $284^{\circ} \mathrm{C}$. NMR $\delta_{\mathrm{Me}_{4} \mathrm{Sl}^{\mathrm{MMS}-\mathrm{d}_{6}} ;} ; .08(3 \mathrm{H}, \mathrm{s}), 5.60(1 \mathrm{H}, \mathrm{s}), 7.40$ $(5 \mathrm{H}), 10.81$ (1 H, broad).

2-Isopropylguanidino-and 2-benzylguanidino-4-hydroxy-6-methylpyrimidines (1 and 2) were prepared in the same way. Similarly, 4-hydroxy-6-phenylpyrimidine derivatives $(5,6)$ were synthesized using ethyl benzoylacetate instead of ethyl acetoacetate.

\section{2-Phenylpropylguanidino-4,6-dimethylpyrimidine (4)}

To the ethanolic solution of phenylpropylbiguanide ( 0.02 mole), acetylacetone $(0.04$ mole) was added and heated under reflux for $2 \mathrm{hr}$. After cooling, the product was collected and recrystallized from ethanol, giving white needles. Yield $2.1 \mathrm{~g}(36 \%)$. M.p. $195-7^{\circ} \mathrm{C}$. NMR $\delta_{\mathrm{Me}_{4} \mathrm{Si}}^{\mathrm{CDCl}_{3}} ; 1.99$ (2 H, quartet), 2. 39 $(3 \mathrm{H}, \mathrm{s}), 2.80(2 \mathrm{H}, \mathrm{t}), 3.33(2 \mathrm{H}, \mathrm{t}), 6.57(1 \mathrm{H}, \mathrm{s}), 7.39(5 \mathrm{H})$.

\section{2-Methylguanidino-4-phenyl-6-methylpyrimidine (9)}

To the ethanolic solution of methylbiguanide ( 0.02 mole), benzoylacetone (0.02 mole) was added and heated under reflux for $2 \mathrm{hr}$. Then, the solvent was evaporated to a small portion and ether was added to the residue. The product precipitated was collected and recrystallized from aqueous ethanol. Yield 1.0 g (21\%). M.p. $197-8^{\circ} \mathrm{C}$. NMR $\delta_{\mathrm{Me}_{4} \mathrm{CI}}^{\mathrm{CDCl}} ; 2.51(3 \mathrm{H}, \mathrm{s}), 3.03(3 \mathrm{H}, \mathrm{s}), 7.13$ $(1 \mathrm{H}, \mathrm{s}), 7.63(3 \mathrm{H}), 8.17(2 \mathrm{H})$.

Other 4-phenyl-6-methylpyrimidine derivatives $(7,8,10)$ were also obtained in the same way.

\section{2-Phenethylguanidino-4-hydroxy-5-ethyl-6-methylpyrimidine (13)}

To the ethanolic solution of phenethylbiguanide (0.02 mole), ethyl 2-ethylacetoacetate was added and heated for an hour. The precipitate was collected and thoroughly washed with methanol. The crude product was recrystallized from ethanol. Yield $3.0 \mathrm{~g}(50 \%)$. M.p. $194^{\circ} \mathrm{C}$. NMR $\delta_{\mathrm{Me}_{4} \mathrm{Si}}^{\mathrm{DMSO}}{ }^{\mathrm{d}} ; 1.05(3 \mathrm{H}, \mathrm{t})$, $2.11(3 \mathrm{H}, \mathrm{s}), 2.47$ ( $2 \mathrm{H}$, quartet), $3.03(2 \mathrm{H}, \mathrm{t}), 3.54$ ( $2 \mathrm{H}$, quartet), $7.42(5 \mathrm{H}$, s).

\section{2-Benzylguanidino-6-oxo-3,4,5,6-tetrahydropyrimidine (14)}

To the solution of benzylbiguanide $(0.02 \mathrm{~mole})$ in $5 \mathrm{ml}$ of dimethylformamide was added with stirring $2 \mathrm{~g}$ (0.02 mole) of ethyl acrylate at room temperature and the mixture was stood for 2 days. The crystals separated were collected by filtration, washed with ethanol and recrystallized from ethanol. Yield $1.5 \mathrm{~g}(31 \%)$. M.p. $190^{\circ} \mathrm{C}$. 
Other compounds than those described were synthesized by the methods reported previously (Shuto et al., 1974; Furukawa et al., 1971).

Biological test.

\section{Test for Pellicularia sasakii}

Pellicularia sasakii was grown in a medium containing $20 \mathrm{~g}$ of bran, $15 \mathrm{~g}$ of chaff and $30 \mathrm{ml}$ of a $0.5 \%$ pepton solution, at $28^{\circ} \mathrm{C}$ for 7 days, then three-fold volume of chaff and $60 \mathrm{ml}$ of the pepton solution were added and blended thoroughly. After standing under the condition of $28^{\circ} \mathrm{C}$ and $97 \%$ relative humidity for $24 \mathrm{hr}$, the mixture was supplied for inoculation. The rice seedlings at the 5-leaf stage were transplanted in a pot (1/5000 are), and were grown in a green house for 60 days. In a preventive test, a test solution (10 $\mathrm{ml}$ per pot) in a concentration of $500 \mathrm{ppm}$ level was applied to the plant by spraying. One day after, a $3 \mathrm{~g}$ lot of the Pellicularia sasakii mixture was applied at the foot of the plant. In a curative test, one day after inoculation of $\mathbf{P}$. sasakii, a test solution $(10 \mathrm{ml})$ was sprayed onto the plants. The treated plants were grown under the condition of $28^{\circ} \mathrm{C}$ and $97 \%$ relative humidity. After 4 days, the length of the diseased spots was measured and then the relative preventive or curative activities were calculated by the following equation.

$$
\text { Relative activity }=\left(1-\frac{\begin{array}{l}
\text { Total length of the diseased spots for the } \\
\text { cheminalrtreated plants }
\end{array}}{\text { Total length of the diseased spots for control }}\right) \times 100
$$

\section{Test for Pyricularia oryzae}

After culturing 10 days on a slant straw-extract agar medium, spores of Pyricularia oryzae were collected. The suspension of the spores was supplied for inoculation. In a preventive test, $15 \mathrm{ml}$ of a test solution was applied by a sprinkler onto the 30-day rice plant seedlings in a pot. The following day, the spore suspension was sprayed on the plants to inoculate the pathogen. In a curative test, $15 \mathrm{ml}$ of a test solution was applied for each pot one day after inoculation of P. oryzae. After 10 days in a green house at $28^{\circ} \mathrm{C}$, the number of diseased spots was counted and the relative activity was calculated by the following equation:

$$
\text { Relative activity }=\left(\begin{array}{c}
\text { Total number of diseased spots for the } \\
\text { chemical-treated plants }
\end{array}\right) \times 100
$$

\section{Test for Pseudoperonospora cubensis}

Seeds of cucumber were immersed in distilled water for $24 \mathrm{hr}$ at $28^{\circ} \mathrm{C}$ and then a seed was allowed to germinate in a cup $(\phi=9 \mathrm{~cm})$. After 18 days, 5 $\mathrm{ml}$ of a test solution was sprayed on the plant, then the plant was kept under the condition of $25 \sim 26^{\circ} \mathrm{C}$ and $80 \%$ relative humidity. The following day, the spore suspension of Pseudoperonospora cubensis was inoculated on 3 points of the second leaf of the plant. After 10 days under the condition of $20^{\circ} \mathrm{C}$ and $95 \%$ relative humidity, the degree of infection was calculated out as the protective value by the similar equation described above. The results are shown as the 
minimum inhibiting concentration (MIC) which was defined as the lowest concentration with the protective value of more than $90 \%$ (Table 4).

Antiviral test against tobacco mosaic virus

The ordinary strain of tobacco mosaic virus (TMV) was supplied by the Institute for Plant Virus Research.

The test plant was Nicotiana tabacum L. cv. Xanthi-nc.

1) Inhibition of local lesion formation; $\operatorname{TMV}(8 \mu \mathrm{g} / \mathrm{ml})$ was inoculated on a tobacco leaf. After $30 \mathrm{~min}$, a solution of a test compound was applied to one half of the leaf. The other half was treated with deionized water in a similar manner. After 4 days, the number of local lesions formed was counted. For each test 8 leaves from 2 plants were used. The inhibition rate of lesion formation was calculated by the following equation:

Total number of local lesion for the

Inhibition rate $=\left(1-\frac{\text { chemical-treated leaves }}{\text { Total number }}\right) \times 100$

When the inhibition rate was below $30 \%$, the result was indicated with a minus sign, (-), in Tables 5 and 6.

2) Inhibition of multiplication ; $\mathrm{TMV}(2 \mu \mathrm{g} / \mathrm{ml})$ was inoculated on tobacco leaves and allowed to stand under fluorescent lamps (1000 lux) at $31^{\circ} \mathrm{C}$ for 24 $\mathrm{hr}$. Then each leaf was divided into two parts from the midrib. One part was floated on a solution of a test compound and the other half on deionized water. They were kept for $24 \mathrm{hr}$ under the same conditions as mentioned above. Then, during lesion formation they were kept at $21^{\circ} \mathrm{C}$. The size of local lesion formed was measured. The effect of a chemical on virus multiplication was shown as follows:-, the size of lesion is corresponding to that of control ;+, the size of lesion is smaller than that of control; $H$, the size of lesion is extremely smaller than that of control.

\section{RESULTS AND DISCUSSION}

Table 3 shows the fungicidal activities of some guanidinopyrimidines. In the fungicidal test to Pellicularia sasakii, the average length of the diseased spots of the plants treated with 2-benzylguanidino-4-phenyl-6-methylpyrimidine (17) was $0.4 \mathrm{~mm}$ and the relative protective rate was $97.1 \%$. In the curative test the length of the diseased spots was $0.6 \mathrm{~mm}$ and the relative activity was $93.9 \%$. Therefore, at a relatively high concentration the compound was as effective as validamycin against Pellicularia sasakii. The sporecidal activity of the same compound against Pyricularia oryzae was almost equal to that of edifenphos, but the curative activity was less effective than the latter.

Against Pseudoperonospora cubensis, 4,6-dimethylpyrimidine (4 and 16) and 4phenyl-6-methylpyrimidine derivatives $(8,10$ and 17) showed relatively strong activities. In general, 4-phenyl-6-methylpyrimidines were more effective. Especially, 2-phenylpropylguanidino-4-phenyl-6-methylpyrimidine (8) completely prevented the invasion of the pathogen at a level of $60 \mathrm{ppm}$. The compound containing a hydroxy group in the pyrimidine ring (2 and 13) showed 
Table 3. Fungicidal activities of guanidinopyrimidines.

\begin{tabular}{|c|c|c|c|c|c|c|c|}
\hline \multirow[b]{2}{*}{ No. } & \multirow[b]{2}{*}{$\mathrm{R}_{1}$} & \multirow[b]{2}{*}{$\mathrm{R}_{2}$} & \multirow{2}{*}{$\begin{array}{l}\text { Conc. } \\
\text { (ppm) }\end{array}$} & \multicolumn{2}{|c|}{ Pellicularia sasakii } & \multicolumn{2}{|c|}{ Pyricularia oryzae } \\
\hline & & & & $\begin{array}{l}\text { Protective } \\
\text { Effect }(\%)\end{array}$ & $\begin{array}{l}\text { Curative } \\
\text { Effect }(\%)\end{array}$ & $\begin{array}{l}\text { Protective } \\
\text { Effect }(\%)\end{array}$ & $\begin{array}{c}\text { Curative } \\
\text { Effect }(\%)\end{array}$ \\
\hline $\begin{array}{c}4 \\
16 \\
17\end{array}$ & $\begin{array}{l}\mathrm{Ph}\left(\mathrm{CH}_{2}\right)_{3} \\
\text { PhCH, } \\
\text { Edifenphos } \\
\text { Validamycin }\end{array}$ & $\begin{array}{l}\mathrm{CH}_{3} \\
\mathrm{CH}_{3} \\
\mathrm{Ph}\end{array}$ & $\begin{array}{r}505000 \\
500 \\
300 \\
30\end{array}$ & $\begin{array}{c}13.216 .2 \\
97.1 \\
100-\end{array}$ & $\begin{array}{c}0 \\
93.9 \\
91.8\end{array}$ & $\begin{array}{l}84.55 .19 \\
97.5 \\
98.3\end{array}$ & $\begin{array}{r}68.79 .12 \\
43.6 \\
97.8 \\
-\end{array}$ \\
\hline
\end{tabular}

Table 4. Fungicidal activity against Pseudoperonospora cubensis and regression analysis of structure-activity relationship.<smiles>[R]c1nc(NC(=N)N([R2])[R])nc(C)c1[R]</smiles>

\begin{tabular}{|c|c|c|c|c|c|c|c|c|}
\hline \multirow{2}{*}{ No. } & \multirow{2}{*}{$\mathrm{R}_{1}$} & \multirow{2}{*}{$\mathrm{R}_{2}$} & \multirow{2}{*}{$\mathrm{R}_{3}$} & \multirow{2}{*}{$\mathrm{R}_{4}$} & \multirow{2}{*}{$\begin{array}{r}\text { MIC } \\
(\mathrm{ppm})\end{array}$} & \multirow{2}{*}{$\pi_{T}$} & \multicolumn{2}{|c|}{$\log 1 / \mathrm{MIC}$} \\
\hline & & & & & & & Obs. & Calcd.* \\
\hline $\begin{array}{c}2 \\
4 \\
10 \\
13\end{array}$ & $\begin{array}{l}\mathrm{PhCH} \\
\mathrm{Ph}\left(\mathrm{CH}_{2}\right)_{3} \\
\mathrm{Ph}\left(\mathrm{CH}_{2}\right)_{3} \\
\mathrm{CH}_{3} \\
\mathrm{Ph}\left(\mathrm{CH}_{2}\right)_{2}\end{array}$ & $\begin{array}{l}\mathrm{H} \\
\mathrm{H} \\
\mathrm{CH}_{3}\end{array}$ & $\begin{array}{l}\mathrm{OH} \\
\mathrm{CH}_{3} \\
\mathrm{Ph} \\
\mathrm{Ph} \\
\mathrm{CH}_{3}\end{array}$ & $\begin{array}{l}\mathrm{H} \\
\stackrel{\mathrm{H}}{\mathrm{H}} \\
\mathrm{CH}_{2} \mathrm{CH}_{3}\end{array}$ & $\begin{array}{l}>500 \\
5002.5 \\
>500 \\
500\end{array}$ & $\begin{array}{l}4.636 .26 \\
3.63\end{array}$ & $\begin{array}{l}-2.3981 .796 \\
-2.699\end{array}$ & $\begin{array}{l}-2.3551 .786 \\
-2.704\end{array}$ \\
\hline $\begin{array}{l}16 \\
17\end{array}$ & $\begin{array}{l}\mathrm{PhCH}_{2} \\
\mathrm{PhCH}_{2}\end{array}$ & $\begin{array}{l}\mathrm{H} \\
\mathrm{H}\end{array}$ & $\mathrm{Ph}$ & $\mathrm{H}$ & 125 & $\begin{array}{l}3.63 \\
5.26\end{array}$ & $\begin{array}{l}-2.699 \\
-2.097\end{array}$ & $\begin{array}{l}-2.704 \\
-2.135\end{array}$ \\
\hline
\end{tabular}

$* \log 1 / \mathrm{MIC}=0.349\left(\pi_{T}\right)-3.971$

no activity. This fact is contrary to the results obtained from the investigation of dimethirimol and its analogues, in which case the hydroxy group plays an important role in its activity (Woodcock, 1972).

Table 4 shows values of MIC of the compounds tested, together with the hydrophobic parameters, $\pi_{T}$, which were obtained as the sum of each substituent-constant of every substituent of a guanidinopyrimidine based on the data of Leo et al.(1971). A regression analysis gave a good correlation as shown in the following equation.

$$
\begin{array}{ccc}
\log 1 / \mathrm{MIC} & =0.349 & \left(\pi_{T}\right)-3.971 \\
\mathrm{n} & \boldsymbol{r} & s \\
5 & 0.997 & 0.034
\end{array}
$$

On the other hand, the relation between the activity and the ionization con- 
Table 5. Antiviral activity of guanidinopyrimidines against tobacco mosaic virus.

$\begin{array}{clllll} & & & \\ \text { Inhibitory Effect (\%) }\end{array}$

* Emulsifier was used.

Table 6. Antiviral activity of guanidinopyrimidines to tobacco mosaic virus.<smiles>[R]c1cc([R])nc(NC(N)N([R2])[R])n1</smiles>

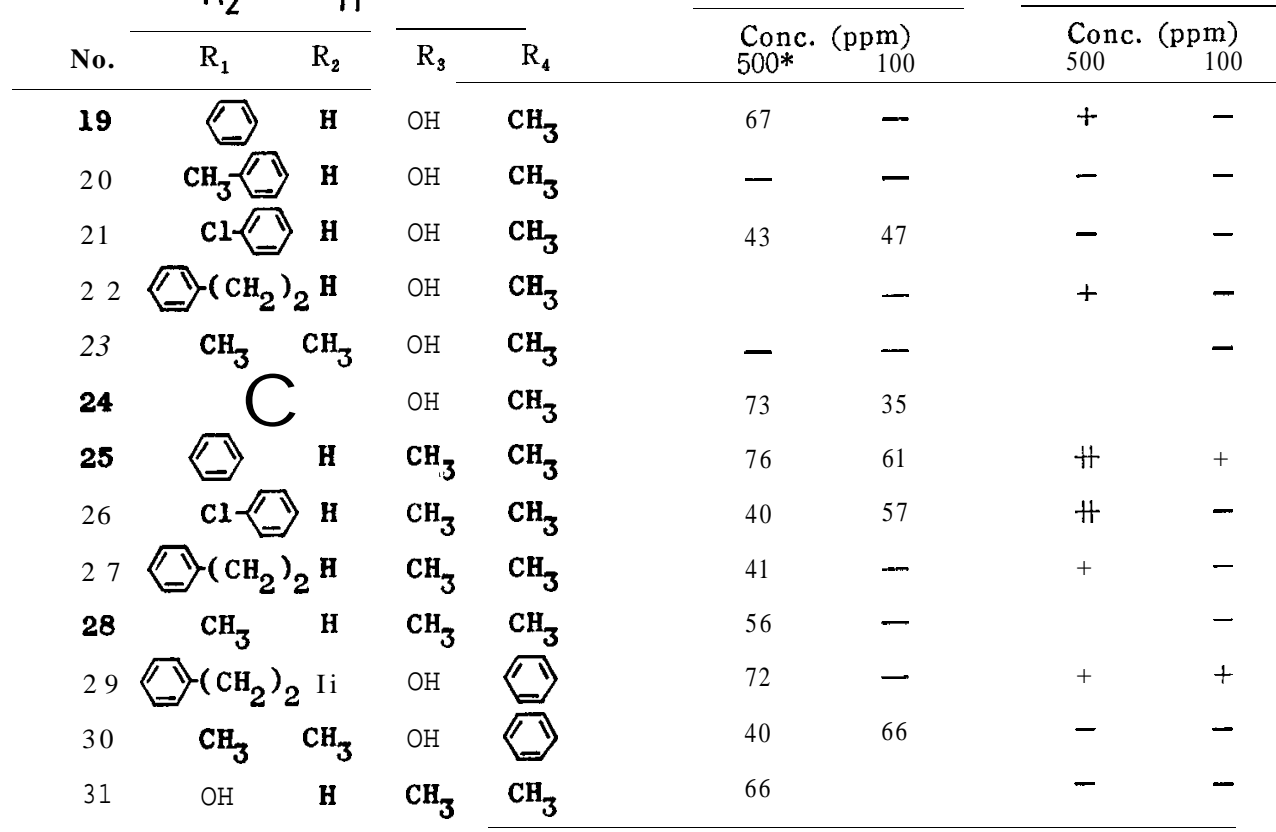

* All of the chemicals tested were phytotoxic at this concentration. 
stants (electronic parameter) was not observed. In general, it is known that the permeability of a drug through biological membranes correlates to the hydrophobic parameters, which were based on the partition coefficients (Hansch, 1971). Therefore, the results suggested that the activity against Pseudoperonospora cubensis might primarily correlate to the ability of penetration to the site of action.

In the antiviral test against TMV, most of the compounds inhibited the formation of local lesion at $500 \mathrm{ppm}$ as shown in Tables 5 and 6 . However, they were also phytotoxic at that concentration. At a level of $250 \mathrm{ppm} \mathrm{2-}$ phenethylguanidino-4-phenyl-6-methylpyrimidine (7) and 2-phenylpropylgua nidino-4,6-dimethylpyrimidine (4) were considerably inhibitory against TMV. 2Dimethylguanidino-4-hydroxy-6-phenylpyrimidine (30) and 2-phenylguanidino4, 6-dimethylpyrimidine (25) were fairly effective at a level of $100 \mathrm{ppm}$; they inhibited lesion formation up to 66 and $61 \% \%$, respectively. As to the effect on multiplication, 2-phenylguanidino- (25) and 2-( $p$-chlorophenyl) guanidino-4,6-dimethylpyrimidines (26) were effective.

\section{ACKNOWLEDGEMENTS}

The authors are indebted to Shionogi Pharm. Co. Osaka for the fungicidal tests and Otsuka Pharm. Co. Osaka for the antiviral tests.

\section{REFERENCES}

Bebbington, R. M., D. Brooks, M. Geoghegan and B. Snell 1969 Ethirimol: A new systemic fungicide for the control of cereal powdery mildews. Chem. Ind., 1512

Curd, F. H. S. and F. L. Rose 1946 Synthetic antimalarials. Part IV. 2-phenylguanidino4-aminoalkylamino-6-methylpyrimidines. $J$. Chem. Soc., 362-366

Elias, R. S., M. C. Shephard, B. K. Snell and J. Stubbs 1968 5-n-butyl-2-dimethylamino-4hydroxy-6-methylpyrimidine : A systemic fungicide. Nature (Lond.), 219: 1160

Elslager, E. F., L. M. Werbel, A. Curry, N. Headen and J. Johnson 1974 Synthesis and antimalarial effects of 1-(3,4-dichlorophenyl)-3-[4-[(1-ethyl-3-piperidyl)amino $]-6-\mathrm{me}^{-}$ thyl-2-pyrimidinyl guanidine and related substances. $J$. Med. Chem., $17: 75-100$

Furukawa, M., Y. Fujino and S. Hayashi 1971 Reaction of biguanides and related compounds. I. Reaction of biguanides with $\beta$-diketone. Chem. Pharm. Bull., 19: 2284-2288

Hansch, C. 1971 Quantitative structure-activity relationships in drug design. In "Drug Design," Vol. 1, ed. by E. J. Ariëns, Academic Press, Inc., New York, pp. 271-342

Leo, A., C. Hansch and D. Elkins 1971 Partition coefficients and their uses. Chem. R ev.. 71: $525-615$

Shuto, Y., E. Taniguchi and K. Maekawa 1974 Synthesis of guanidinopyrimidine derivatives and their biological activities. J.Fac. Agr., Kyushu Univ., 18: 221-237

Urbanski, T. and B. Serafin 1967 Potential antimalarial compounds. IX. Pyrimidine derivatives of urea and guanidine. $J$. Med. Chem., 10: 521-525

Woodcock, D. 1972 Structure-activity relationships. In "Systemic Fungicides," ed. by R. W. Marsh, Longman, Inc., London, pp. 34-79 